\title{
The coercive laws of competition in a neoliberal era: the case of forestry in Costa Rica
}

\author{
Brett Sylvester Matulis ${ }^{1}$ \\ University of Leicester, UK
}

\begin{abstract}
Market-oriented forms of conservation are believed to deliver enhanced efficiency in ecosystem management. This greater efficiency is derived from the introduction of competitive mechanisms in resource governance. Market competition, however, produces new social relations that can alter the division of benefits between various actors within the economy and present opportunities for accumulation. The consequent gains in efficiency are not necessarily equitably distributed. Furthermore, the introduction of competition can erode cooperative arrangements designed to assist the poor and politically marginal. Drawing on theories of the 'coercive laws of competition', I seek in this article to understand how competitive structures compel actors to behave in ways that put profit before social or environmental responsibility and encourage self-interested behavior. I explore these ideas in the context of Costa Rican forest conservation, showing that competitive contracting in private forest management has resulted in an uneven distribution of benefits and a comparative advantage for larger landowners. In addition, I also re-think the 'coercive laws' for a neoliberal era.
\end{abstract}

Keywords: competition, neoliberalism, conservation, markets, efficiency, PES

\section{Résumé}

Les types de conservation qui sont orientées vers le marché sont largement considérées pour offrir une efficacité accrue pour la gestion des écosystèmes. Cette plus grande efficacité provient de la mise en place de mécanismes compétitives en matière de gouvernance des ressources naturelles. La compétitivité du marché, cependant, produit de nouvelles relations sociales qui peuvent modifier la répartition des bénéfices entre les différents acteurs de l'économie et des possibilités actuelles d'accumulation. Les gains qui en découlent en matière d'efficacité ne sont pas nécessairement équitablement répartis. En outre, l'introduction de la compétitivité peut éroder les accords de coopération visant à aider les pauvres et politiquement marginal. En utilisant les théories des «lois coercitives de la concurrence», je cherche à comprendre comment la concurrence oblige les acteurs à adopter des comportements qui mettent le profit avant la responsabilité sociale ou environnementale, et encourager un comportement égoïste. J'explore ces idées dans le contexte de la conservation des forêts du Costa Rica. Ici, les contrats dans la gestion des forêts privées a conduit à une répartition inégale des avantages, et un avantage comparatif pour les grands propriétaires fonciers. Je discute également le rôle des «lois coercitives» dans une ère néolibérale.

Mots-clés: la concurrence, le néolibéralisme, la conservation, les marchés, l'efficacité, PES

\section{Resumen}

Se piensa que las formas de conservación orientadas al mercado logran mayor eficiencia en la gestión de las ecosistemas. Esta mayor eficiencia se deriva de la introducción de mecanismos de competencia a la gobernanza de los recursos. Sin embargo, la competencia del mercado produce nuevas relaciones sociales que pueden cambiar la manera en que los beneficios se dividen entre los varios actores participando en la economía, y que pueden presentar nuevas oportunidades para la acumulación. Entonces las mejoras logradas en la eficiencia no necesariamente son compartidas de manera equitativa. Ademas, la introducción de la competencia puede erosionar los arreglos cooperativos diseñados para ayudar a los pobres y los políticamente marginados. En este artículo utilizo teorías de las 'leyes coactivas de la competencia' para entender como las estructuras de competencia fuerzan a los actores a actuar en maneras que privilegian al interés individual, y a la ganancia sobre la responsabilidad social o ambiental. Discuto la conservación forestal en Costa Rica, mostrando que los contratos competitivos que operan en el manejo privatizado de los bosques ha resultado en

\footnotetext{
${ }^{1}$ Dr. Brett Sylvester Matulis, Lecturer, Department of Geography, University of Leicester, LE1 7RH, United Kingdom. Email: bmatulis "at" gmail.com; bsm10 "at" le.ac.uk. The author wishes to thank the anonymous reviewers and the editors who volunteer their labor to maintain this Open Access journal.
} 
una distribución desigual de los beneficios, y una ventaja comparativa para los grandes propietarios. Repienso la idea de 'leyes coactivas' en la epoca neoliberal.

Palabras clave: competencia, neoliberalismo, conservación, mercados, eficiencia, PES

\section{Introduction}

Forestry in Costa Rica has undergone a dramatic transformation over the last several decades. A country once infamous for an unmatched rate of deforestation has become one of the most highly regarded for its conservation achievements. In this transition, the work of the professional forester has shifted from overseeing extraction and managing timber plantations to (mainly) overseeing the conservation of existing forest ecosystems. Under the country's Pagos por Servicios Ambientales (PSA or 'Payments for Environmental Services') program, the forester provides the expert knowledge for managing ecosystems to deliver 'ecosystem services.' These changes in professional practice, however, go beyond simply the type of work being carried out, to include important structural changes to the way work is organized. The decentralization and privatization of the labor force has re-shaped the experience of work and the operation of the PSA program, which has, in turn, brought about an individualization of landowner participation. These changes have had important effects on PSA contracting and, ultimately, on who benefits from the ecosystem service payments that are made.

This trend in Costa Rica is part of a broader shift towards the neoliberalization of nature that has been observed in environmental governance more generally (Arsel and Büscher 2012; Brockington and Duffy 2010; Castree 2008a; Castree 2008b; Heynen and Robbins 2005; McCarthy and Prudham 2004). The expansive work on neoliberal natures provides a potent conceptual framework for understanding the ideological transformation of environmental governance and its material implications; for example in the links between privatization and the 'weakened the position of the citizen' in resource governance (Swyngedouw 2005), in the marketization of ecosystem service commodities (Robertson 2004; Sullivan 2013), in the re-regulation of conservation through commodification (Igoe and Brockington 2007), and in the production neoliberal environmentalities (Fletcher 2010). Yet little has been offered to understand how the introduction of competitive mechanisms within environmental governance works to promote self-interest and advance capitalist social relations.

This article explores the neoliberalization of forestry work in Costa Rica that has occurred through the promotion of competitive PSA contracting, situating analysis in a theoretical context of the 'coercive laws of competition.' It seeks to adjust these 'laws' to a present-day (neoliberal) context while uncovering the ways that the competitive system has resulted in an uneven distribution of benefits and a comparative advantage for larger landowners. These latter findings complement previous studies that have made similar observations (Lansing 2014).

In the following section, I first articulate the conceptual frame for the article by drawing upon Marxist theories of competition and ideas around the scalar tensions between competition and cooperation. At first glance it may seem that the 'coercive laws' (which were developed in the context of $19^{\text {th }}$ century industrial capitalism) have little relevance to conservation practice in $21^{\text {st }}$ century rural Costa Rica - indeed many incongruities between these contexts exist - but, as I will explain, important insights may still be drawn when the concepts are adapted to a contemporary setting. Following this conceptual framing, I then provide context for what has occurred in Costa Rica, through a detailed overview of the forestry industry, including its privatization and decentralization. Following that, I discuss the effect of these actions on the operation of the PSA by drawing on three organizations that have been involved in contracting. Then I explore the tensions between competition and cooperation through an assessment of the (now defunct) group contracting mechanism, and I illustrate how competition has not decreased the cost of participation for all landowners, but rather has disproportionately benefited the larger and (usually) wealthier among them. Finally, I return to the theoretical framework of the article and conclude with a discussion of how we must re-think the coercive laws of competition for a neoliberalized economy. 


\section{Competition and cooperation}

Under free competition, the immanent laws of capitalist production confront the individual capitalist as a coercive force external to him. (Marx 1976: 381)

Harvey (2010a) identifies the 'coercive laws of competition' as the conditions that impel actors within a capitalist system to pursue accumulation and profit-maximization, despite the destructive consequences it may bear upon nature and society. As he explains, if an actor in a capitalist system does not "reinvest in expansion and a rival does, then after a while [he or she is] likely to be driven out of business" (2010a: 43). Actors within the system "need to protect and expand [their] market share" (Harvey 2010a: 43), in order to remain viable. Regardless of what other motivations or desires they might have, the coercive laws of competition impel pursuit of actions that maximize profit and accumulate wealth.

One of the most poignant examples of this is the Ermen and Engels Mill of Victorian Manchester in the UK, which was underwritten by the wealthy father of Friedrich Engels, Marx's closest colleague. Engels himself spent two decades working in management at the mill, and found that even he could not escape these coercive laws (Hunt 2010). His own writing described in unsettling detail the deplorable conditions of the working poor in Victorian Manchester, and yet he could do little to change it (Engels 1993). Improvement of conditions and payment of fair wages would have rendered the company uncompetitive and ensured its failure. If the mill failed, it would simply have been replaced by a rival that was willing to submit to the coercive laws. Regardless of what Engels might have wanted, he was constrained by the system in which society operated. While there is a degree of irony in this co-author of the The communist manifesto profiting from the labor of others and, indeed, in that those profits supported the work of Marx himself (Hunt 2010), there are structural barriers to what could have been achieved and that compel a particular relationship between actors within a capitalist economy.

In addition to constraining the actions of individual capitalists, these coercive laws cause innovations that expand profit to propagate throughout the entire system, regardless of the social or environmental harm they may cause. Competition requires the uptake of productivity-raising innovations - whether they be technological innovations or new exploitative practices - so that the advantage of rivals can be overcome. As Marx explains, the individual capitalist "who applies the new method of production' must 'sell his [sic] goods under their social value"' (1976: 436). ${ }^{2}$ The result is that the innovator captures a greater market share and surplus value compared to rivals whose goods require greater labor investment. This means that rivals must adopt the same innovations in order to recover their shares and remain viable. In this way, it is actually the law of the determination of value by labor-time, "acting as a coercive law of competition", that is forcing the innovator's competitors to adopt the new method of production (Marx 1976: 436). Ultimately, it is the structural dynamics of the capitalist system that drive the uptake of new technologies or practices, even if they are destructive to society or the environment.

A question of important relevance to the material implications of competition concerns the scales at which these coercive laws operate. The economy, after all, is not composed of entirely disconnected actors competing in every way. A great deal of cooperation occurs between rivals at particular scales. As Neil Smith points out, corporations cooperate broadly within nation-states to influence the regulatory environment and establish common labor laws, infrastructure, communications networks, and national defense, even while they may compete for market share, product identity, and technological advantage (Smith 2003: 228-229). Importantly, the scales at which the tensions between competition and cooperation are negotiated are not fixed givens, or neutral frames. They are themselves produced within the context of social, economic, and political relationships that enable or proscribe particular forms of social enterprise. Thus, the scales at which

2 This is because the value of goods decreases when innovation reduces the labor required to produce them, which in turn creates a difference between the 'individual value of the cheapened commodity' and the average value ascribed by society (Marx 1976: 436). 
economic actors are brought into competition or encouraged to cooperate are not arbitrary; they emerge from existing power relations and serve narrow interests (or are, otherwise, deliberately produced by powerful actors to achieve some specific political or economic ends). There is a certain intentionality to the scalar organization of the economy that serves to elevate the interests of specific actors above those of others. As such, "the demarcation of scale should be seen as absolutely central to the processes and politics of uneven geographical development" (Smith 2003: 229).

In Costa Rica, there have recently been two significant scalar shifts in the political and economic organization of the forestry industry: the individualization of forestry work, and the individualization of landowner participation. Both have occurred in a neoliberal push to dissolve collective organization and reconstitute particular power structures. As I will demonstrate below, the coercive laws of competition are at play in the new modes of forestry management planning, as professional foresters have been organized as private contractors that must compete to provide management-planning services. This organization has been advanced under the presumption (and pretext) that it will result in increased efficiency (through a process of downward bidding wherein prices stabilize at the lowest possible rates). The effect of this competition, however, has been to place profit-maximization ahead of social or environmental responsibility and to produce an uneven distribution of benefits, as the savings from efficiency gains are delivered to the largest and wealthiest participants in the program. Furthermore, with regard to the PSA participants themselves, I will explore the tensions between competition and cooperation in the second scalar shift, which saw the replacement of community level contracting with the coordination of contracts at the individual level, further compounding the problem of large landowner advantage.

\section{Forestry in Costa Rica}

In moments of transition there are opportunities for political and economic transformation as legal frameworks are amended and governing structures are renegotiated. One such moment arose in the aforementioned reorientation of Costa Rica's forestry sector from extraction to conservation. In stark contrast to its history, forestry in Costa Rica today is primarily about management for conservation purposes (Evans 1999), and the PSA is the centerpiece of national forest policy (Fletcher and Breitling 2012; Matulis 2013). The program was designed as a market-based mechanism for conservation and forest restoration (Sage and Sánchez 2002). In its idealized form, it aims to establish direct financial relationships between the 'users' and 'providers' of ecosystem services. In practice, the government acts as an intermediary for most transactions, using taxes and tariffs (not pure markets) to finance the program (Fletcher and Breitling 2012). Under the persistent influence of the World Bank and market-oriented factions within the government, however, financing mechanisms have been (and are continuing to be) revised so that they align to market ideology as much as possible (Matulis 2013; Matulis in press).

Presently, the PSA is managed by FONAFIFO, the quasi-governmental agency originally created to oversee the financial assets of national forestry programs. FONAFIFO has its origins in a period of broader government decentralization during the early 1990s (Fletcher and Breitling 2012). The Ministry responsible for environmental policy at the time, MIRENEM, was led by René Castro, who enthusiastically pursued policies that relied on "cutting-edge technical and administrative skills and ideas learned abroad" (Silva 2003: 102). These took a decidedly neoliberal disposition, emphasizing "administrative decentralization ... and [relying] on market-oriented policy instruments for both regulation and financing" (Silva 2003: 102). When it was designed, FONAFIFO was given a special hybrid public/private status to allow greater flexibility in managing various revenue streams, allowing it access to public finances, but sheltering its private revenue streams from ordinary bureaucratic channels.

Responsibility for forestry financing had been transferred to FONAFIFO from the Dirección General Forestal (DGF or 'General Forestry Directorate'), which was the agency established under Costa Rica's first Forestry Law in 1969 (Law 4465) to regulate and control forestry activities (FONAFIFO 2005; Le Coq et al. 2015). The DGF was further empowered by the second Forestry Law in 1986 (Law 7032) and organized around a traditional 'top-down', command and control model that employed professional foresters to oversee 
and monitor forestry activities (Lansing 2013). It was also an important forum for peasant organizations and a champion of 'social forestry' policies that incorporated social development into forest management. The agency, however, was chronically understaffed, under-equipped, and suffered from low morale. Concentration of staff in San Jose also meant that oversight of forestry activities was limited and corruption commonplace (Silva 2003).

Foresters employed by the DGF were responsible for a broad array of management activities including permitting, accounting, oversight of resource extraction, forestry research, long-range planning, and formulation of industrial policy. As its responsibilities expanded, the ill-equipped agency acquired a reputation for being ineffective. Eventually a "general consensus developed ... that the DGF had too many responsibilities and that consequently it was unable to accomplish any of them well" (Silva 2003: 103). The agency's responsibilities were gradually stripped away so that it could focus on control and oversight.

\section{Privatizing the labor force}

The DGF resisted inter-agency moves to decrease its authority, but further administrative restructuring facilitated the transition over the agency's objections. The Environment Law of 1995 (Law 7554) transformed MIRENEM into MINAE (the Ministry of Environment and Energy) which then unified forest management under a new administrative body called SINAC, the Sistema Nacional de Areas de Conservación (Navarro and Theil 2007). This re-organization allowed power relationships to be re-ordered and control to be reconsolidated. By appointing a single person to head all three departments concerned with forest management (DGF, National Park Service, and Wildlife Service), SINAC consolidated control of forest policy under the new market-oriented faction that had been ushered in by René Castro. While the move had the beneficial effect of dislodging entrenched extraction-oriented thinking, it simultaneously eliminated the institutional advocate for social development within forest policy.

Responsibility for managing forestry finances was, at this point, transferred from the DGF to FONAFIFO, and the various trust funds were consolidated into a single account (FONAFIFO 2005). Eventually, the foresters themselves were transferred out of government employment, and forest management was organized into private regencias (individualized supervision of forest properties by independent foresters). The move was precipitated by Castro's market-oriented faction and motivated by the idea that private independent contracting of forest management services would create competition and place downward pressure on service costs. With its financing, control, and oversight responsibilities effectively privatized, the DGF was a mere shell of an organization. It was eliminated entirely after passage of the 1996 Forest Law (Law 7575). At this point, forest policy took "a decidedly more market-friendly tack" (Silva 2003: 105). As Silva explains, "[c]ommand and control were out; liberalizing and privatizing permitting, extraction, and transportation were in" (2003: 105).

One of the more significant effects of the DGF's demise was on the conduct of forestry work. Under the regencia system, professional forestry engineers operate as independent contractors in the private sector. Regentes forestales, or 'forestry regents', as they are called, are responsible for the on-the-ground implementation of most aspects of forest management in Costa Rica, including conservation under the PSA. They are trained at one of two technical institutes and then licensed by their professional association, the Colegio de Ingenieros Agrónomos or Institute of Agricultural Engineers. They are not employed by the government or FONAFIFO, but rather are paid directly by their client landowners (Navarro and Theil 2007). Apart from the submission of prepared PSA applications and the occasional inspection, they have little contact with official authorities. This decentralization has created a private industry of professional foresters that operates independently from most government functions.

The idea behind the regente system was that it would "free public sector personnel to concentrate on inspection and oversight [of regentes] instead of on the permitting process [itself]" and, thus, "eliminate opportunities for the corruption of public officials" (Silva 2003: 105). By removing their authority to issue management permits, officials would (theoretically) be more honest in their compliance inspections, as opportunities for bribes and kickbacks would be reduced. Regentes are supposedly unable to accept such 
temptations, since they are subject to inspection. As Navarro and Theil (2007: 19) suggest, however, the verification system is understaffed and inadequately financed. Additionally, the compensation methods of the private system have introduced a serious conflict of interest, as regentes are paid only when they attest that their client landowners are compliant with the management plans outlined in their PSA contracts (Interview \#14, 3 Nov 2011). Obviously, the integrity of the system is a matter of accountability, not an issue of whether forest managers are publicly or privately employed. Nevertheless, the ill-repute of DGF foresters contributed to the industry's ultimate privatization.

A stronger explanation of the effort to move foresters out of government employ is that it would "free central office personnel to devote more time to agenda setting, planning, and policy formulation", which, under current administration, has meant pursuit of "cutting-edge market-oriented strategies to fund biodiversity conservation" (Silva 2003 110). Beyond accountability and policy innovation, however, privatization of the forestry profession was also presumed to increase efficiency, as regentes would be required to compete for clients and, thus, drive down costs. While some regentes indicate that this has begun to occur (Interview \#1, 7 Feb 2012; Interview \#2, 30 Jan 2012), the benefits of the competitive system have not been evenly distributed. As I will show, the result has primarily been lower per-hectare enrollment costs for large landowners, not across-the-board lower rates for all participants.

\section{Operation of the PSA}

In order to participate in the PSA, a landowner must present an application to FONAFIFO consisting of a management plan and other supporting documents (such as land title or documentation of secure possession, proof of payment of taxes, and evidence of good standing with the national insurance program) (Pagiola 2008). Regentes are technically only required for preparation of the management plan and annual inspections, though they typically assist in the entire application process. Landowners contract regente services on the private market and compensate them through a percentage of the payments received from PSA enrollment (Figure 1).

\section{Independent contractors}

While some regentes work as salaried staff for non-governmental organizations, private businesses, or cooperatives, most are independent contractors. The rate that independent regentes are paid is agreed upon with each of their client landowners and set in a contract. Typically, this is between 10 and $12 \%$ of the annual PSA payment (Interview \#3, $14 \mathrm{Feb} 2012$ ), but the rate is highly contingent upon the size of the land enrolled. The smallest landowners are frequently charged upwards of 18\% (Interview \#2, 30 Jan 2012).

If the application is accepted and the land is enrolled in the PSA, the landowner must manage the land according to the regente's plan in order to receive payment. Routine inspections are carried out by the regente to ensure that the contract is being followed, and spot checks are performed by FONAFIFO to ensure the integrity of regente reports. These arrangements have important implications for land management practices, which are shifting (under the influence of the PSA) towards more exclusionary forms than have existed historically (Matulis 2015).

Legally, regente fees are limited to $18 \%$ of the environmental service payment received by their client landowners. The rate that is charged in practice is typically determined by contract size, contract modality, and ease of site access (Interview \#1, 7 Feb 2012), all factors that affect the amount of labor required on the regente's behalf. Significantly, the government plays almost no role in regulating these agreements to ensure just outcomes. The $18 \%$ limit is loosely enforced, and poorly informed landowners are occasionally charged above that rate (Interview \#4, Jan 2012). One official closely linked to FONAFIFO even acknowledged being aware of contracts set at rates as high as 50\% (Interview \#5, Feb 2012)! Those that are charged illegally high rates are almost exclusively the smallest landowners. This occurs because, on the smallest contracts, the fee is not great enough below the $18 \%$ limit to generate a living wage for the regente (Interview \#2, 30 Jan 2012). 
While Costa Rican law does specify minimum wages for private industry (Decreto 37784-MTSS), these are of little relevance to self-employed independent contractors like regentes. ${ }^{3}$ It is up to regentes themselves to decide the least they are willing to accept. According to one active regente, the smallest viable conservation contract (without exceeding the 18\% limit) is 30 hectares (Interview \#2, 30 Jan 2012). The administrative expenses of contracts smaller than that simply cannot be justified without charging more than the limit. While the PSA officially allows contracts "from one hectare onward" (FONAFIFO 2005: 40), contracts smaller than 30 hectares and below 18\% will not generate a wage great enough to sustain the regente's livelihood. The effect is that the smallest owners are excluded entirely or illegally charged more than $18 \%$. Only when the property is considerably larger (and, thus, the contract value is considerably high), is there room for competition.

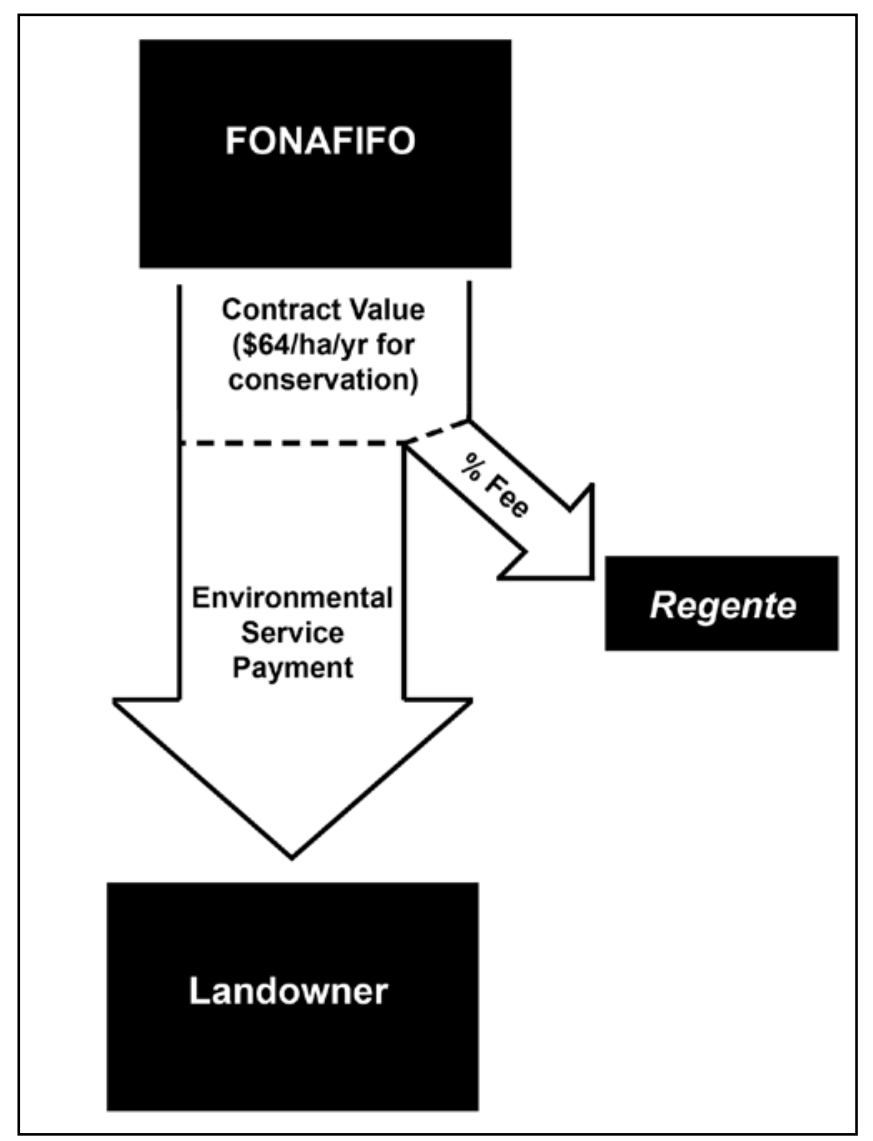

Figure 1: Payment scheme.

Despite the exclusion of the smallest landowners that has resulted from the privatization and deregulation of forestry work, the removal of government safeguards, in this instance, was not viewed as placing a vulnerable population at risk. Rather, it was interpreted as freeing the labor force into a dynamic market where competition would drive down service fees and ultimately benefit landowners. It is based on

3 The Colegio de Ingenieros Agrónomos further sets a guideline professional wage of $\mathbb{C} 20,000 / \mathrm{hr}$ (about $\$ 37 / \mathrm{hr}$ ) that regentes should earn (Colegio 2011). As it is an official 'contact hour' rate (like that a lawyer would charge), however, it also bears little correspondence to actual hourly wages. 
the assumption that competition will compel regentes to charge the lowest amount possible in delivering the services required of them.

\section{Competition}

If the objective of privatizing forestry work was to reduce regente compensation through competitive contracting, there is evidence to suggest that it has succeeded. At the start of the program, most regentes charged a standard across-the-board rate of 18\% for forest management planning (Interview \#6, 13 Jan 2012). This was a matter of convention, as most were unsure of what it would cost them to provide the service, and the mandated maximum became "a sort of de facto standard" (Interview \#7, 23 Feb 2012). As the program progressed, however, regentes began competing for the more lucrative contracts, and rates have fallen as low as 6 or 8\% in some cases (Interview \#1, 7 Feb 2012; Interview \#2, 30 Jan 2012).

The mechanism by which this occurs relates to the coercive laws of competition, through competitive cost-saving changes to practice. Regentes are compelled to lower rates and cut costs in order to obtain contracts and stay in business. Constrained by the threat of losing market share to rivals, they must set aside social and environmental motivations and pursue economic efficiency. Through an iterative process of downward bidding, the price stabilizes at the lowest possible rate, favoring those regentes that are able to deliver services in the cheapest way. According to the neoliberal orthodoxy that instated this system, only competition can prevent 'rational' profit-maximizing agents from concealing information about the 'true cost' of their services and charging unnecessarily high rates. It is the only way, dogma suggests, to align innate self-interest with downward pricing, reveal the true cost of regente services, and eliminate 'waste' in overcompensation. Indeed, lower regente fees are celebrated as a triumph of the free-market system, in that regente compensation has stabilized at the most 'efficient' levels.

Unfortunately, this assessment does not fully appreciate the equity implications of the declining rates. In fact, closer examination reveals that competition has not caused the cost of participation to decline evenly for all involved. As I have indicated already, the smallest landowners, whose contracts are far less lucrative, are still charged upwards of 18\% or more (Interview \#2, 30 Jan 2012; Interview \#4, Jan 2012; Interview \#5, Feb 2012). ${ }^{4}$ Competitive contracting, in other words, has created a differentiated fee schedule that disproportionately benefits the larger landowners, thus exacerbating existing inequities.

\section{Uneven benefits}

The reason for the uneven decline of regente rates concerns the cost of management planning. As would be expected, it costs more to prepare a large contract than it does to prepare a small one. However, as there are many fixed-costs associated with the process (Miranda et al. 2003), large contracts are only marginally more expensive to prepare (Figure 2). This means that the per-hectare cost of preparing a large contract can actually be far lower than it is for a small one. Considering that a regente must do the same paperwork, the same field visits, and the same billing and accounting procedures, regardless of contract size, it matters rather little (in terms of cost) if the contract is for 30 hectares or $250 .{ }^{5}$ However, since payout is a function of contract size (i.e. regentes receive a percentage of the total payment made to their client landowners), this makes large contracts vastly more lucrative.

At the ordinary payment rate of $\$ 64 / \mathrm{ha} / \mathrm{yr}$, the value (to the landowner) of a 250 hectare conservation contract is $\$ 16,000 / y r$, minus regente fees. Likewise, a 30 hectare contract is worth $\$ 1,920 / y r$, minus fees. With only marginally more work required for the large contract that carries a vastly higher payout, there is obviously far greater potential for the regente to profit, as well as far greater potential for savings through

4 This information comes from two experienced regentes and an official with detailed knowledge of contracting practices.

5 Certainly, inspections of larger properties require greater time, but the costs of such field visits are overwhelmingly dictated by other factors - travel to a 30 hectare site may be no less expensive than travel to a 250 hectare site, and administrative procedures may be identical (Interview \#2, 30 Jan 2012). 
regente competition. This means that a regente can offer far lower rates to larger landowners and still generate a living wage. Competition has given a comparative advantage to larger, wealthier landowners and is, thus, contributing to an expansion of wealth disparity.

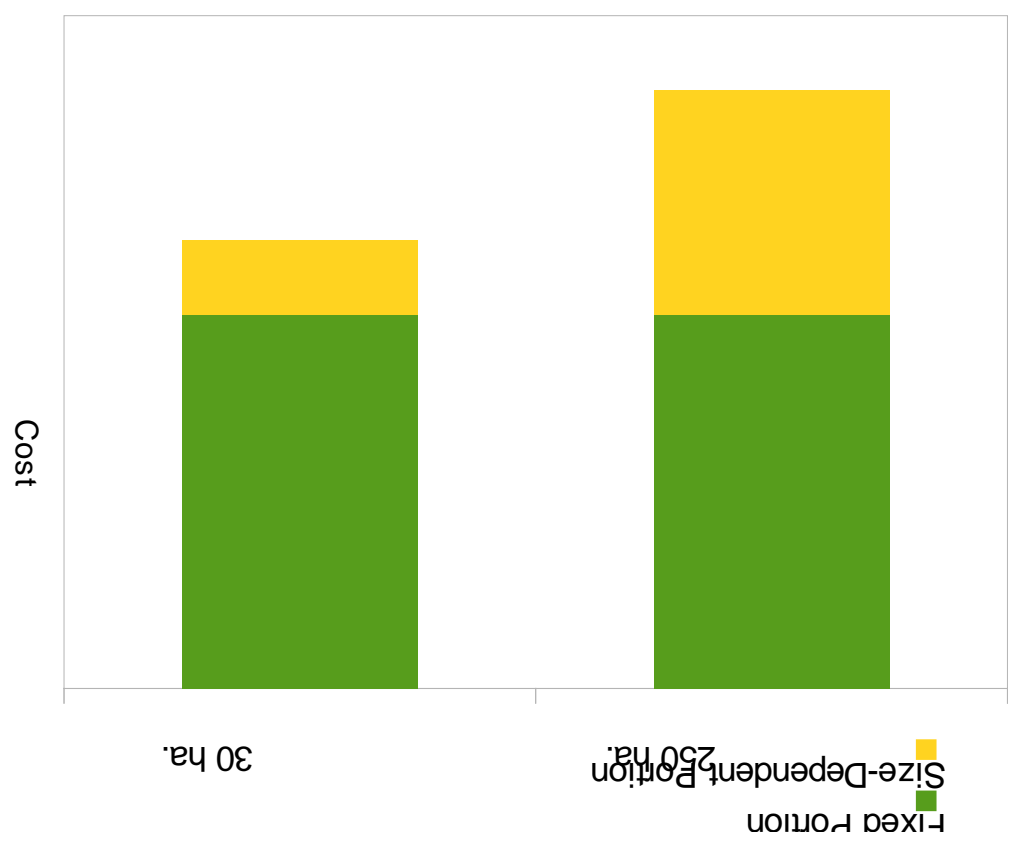

Figure 2: Cost of contract preparation.

To some, however, the uneven decline of regente rates is not a pressing concern and merely reflects the 'true cost' of delivering ecosystem services on a case-by-case basis. Pagiola et al., writing for the World Bank, for example, suggest that payments for ecosystem services "was conceptualized and undertaken as a mechanism to improve the efficiency of natural resource management, and not as a mechanism for poverty reduction" (2005: 239). ${ }^{6}$ Under this reasoning, the PSA should be concerned with efficiency in delivering ecosystem services, rather than equity in regente fees. An official closely linked to FONAFIFO, for example, dismissed the importance of ensuring equitable rates for small landowners, mincing no words in saying that "larger landowners ... are the ones who are more suitable for these type of payments, and since Costa Rica wants [to maximize] environmental services, I don't see any difference to pay them" (Interview \#5, Feb 2012). In other words, if larger landowners can deliver greater services at a lower cost, the PSA can maximize its conservation outcomes by providing a competitive advantage to them. As Porras explains, this is based on a belief that "[l]arge properties managed with a shrewd business perspective will always present better economies of scale than small, fragmented individual farms" (2010: 14). The efficiency gains from favoring larger landowners are, thus, from this perspective, "economically and environmentally justifiable" (Porras 2010: 14-15).

\section{The effect of competition}

In addition to the uneven benefits derived by larger landowners, competitive contracting is also fostering several rather undesirable and more fundamental changes to environmental governance in Costa

6 Importantly, as Miranda et al. indicate, this was not the view of the program's architects; "from the outset the state and various social organisations assumed [the PSA] would contribute to rural poverty alleviation" (2003: i). 
Rica. These include the erosion of alternative motivations, advancement of the profit imperative, and the intensification of self-interested decision-making.

\section{Edging out alternative motivations}

An early mechanism for promoting participation in the PSA program was to have established local NGOs recruit landowners and assist them with application and enrollment. One such organization selected to pilot NGO-driven recruitment was ASANA (Asociación Amigos de la Naturaleza del Pacífico Central y Sur), located near Dominical on the country's central Pacific coast. ASANA employed a salaried regente to draft management plans and enroll landowning community members in the PSA (Interview \#6, 16 Jan 2012). The organization charged an 18\% rate, as most independent regentes and organizations did in the early days, using the revenues to cover its expenses and pay its regente (Interview \#6, 16 Jan 2012). Any surplus was cycled back into the organization to carry out its conservation mission and support community development activities.

By the time the first round of contracts came up for renewal, however, the PSA contracting landscape had changed dramatically: many more regentes had entered the contracting business, landowner demand for participation far outstripped program resources, and independent regentes were offering significantly discounted rates (at least to those with the most lucrative contracts). Moreover, FONAFIFO decided to remove the incentives that encouraged NGO involvement, thus forcing them to compete on the open market. As an officer and member of ASANA explained, "FONAFIFO changed all the rules ... and we had to compete directly with foresters" (Interview \#6, 16 Jan 2012). Under these conditions ASANA found it difficult to keep a regente on staff, as the regentes could earn more money by contracting independently. An officer explained, "no forester would want to work for us if we were taking what [they] normally took for themselves" (Interview \#6, 16 Jan 2012). Organizations like ASANA were effectively priced out of the market. In the officer's words, the changes "pretty much ended the program for organizations like ASANA" (Interview \#6, 16 Jan 2012).

Ostensibly, from the perspective of an outside party, this was a positive development, as lowered rates from competition signify increasing efficiency. On the other hand, the decline of NGO involvement represents a more fundamental (and troubling) shift in the program's operation. Beyond the uneven distribution of benefits that I already explained above, the underlying motivation for PSA contracting was altered when the emphasis shifted from NGOs to individual competitive regentes. ASANA had operated under an ecological mandate and was promoting the PSA because it wanted to expand conservation (Interview \#6, 16 Jan 2012). Independent regentes, on the other hand, are motivated by an entirely different set of objectives. Certainly many (if not all) regentes are gratified by the environmental outcomes of their activities, but they are agents within a framework that compels the pursuit of profit maximization. As the margin between profitability and viability narrows, regentes cannot afford to take insufficiently lucrative contracts, regardless of their social contribution or ecological significance. As one private regente explained, "it's business" and, if a regente is going to "keep his head above the water", "he" must take decisions that sustain the business (Interview \#2, 30 Jan 2012). In other words, regentes are constrained by program structure and forced to base contracting decisions upon their impact to the bottom line.

As organizations like ASANA are edged out of PSA recruitment, the reason for contracting becomes oriented towards the profit motive. The only entities that remain - indeed the only entities that are able to survive - are the ones that are driven to behave as profit maximizing businesses. Competition, in other words, leads to a broader, more fundamental shift towards the profit imperative and away from the various social and ecological imperatives of non-governmental organizations. Regentes themselves - even if they desire to be involved in PSA contracting for altruistic reasons - are compelled by circumstances to engage in the sort of competitive contracting that favors the elite. There is little margin for alternative motivations. 


\section{Fostering self-interest}

Another organization, ATAL, has also experienced setbacks related to the rise of competitive contracting. ${ }^{7}$ Similar to the case with ASANA, ATAL has had difficulty retaining their salaried regentes due to the enhanced opportunity for personal gain derived from independent contracting (Interview \#8, Jan 2012). New regentes are often willing to work at lower-than-average rates, in order to establish their reputation and build their professional networks (Interview \#2, 30 Jan 2012). Once they have secured a portfolio of contracts, however, they are able to more freely and directly compete in the contracting market. The experience of ATAL has been that their trained regentes eventually move on and enter the competitive independent system where they are able to make greater profit (Interview \#8, Jan 2012).

Recently, ATAL's regente left the organization under some rather contentious circumstances. ATAL had held several large PSA contracts with local landowners, which helped to sustain the organization's contracting program and support its other conservation and development activities. Since these contracts were registered in the regente's name, however, he was able to retain these contracts when he left the organization (Interview \#8, Jan 2012). Now, instead of receiving a salary from the organization, the regente receives payment from the enrolled landowners directly - a considerably greater sum than his former salary, given the size of the properties. ATAL was left in a problematic situation because, without the revenues from their large contracts, their operations are severely underfunded. It is yet unclear whether matters will (or can) be settled through legal action.

By operating independently, the regente is deriving immense personal benefit, while the organization (and the community that depends on it) is being deprived of important resources. The transfer of these contracts from ATAL to the independent regente constitutes the transformation of shared development resources into private profit. Not only does the competitive contracting system enable this sort of selfinterested behavior, it actually encourages it (on the grounds that the independent regente will be able to provide contracting services more efficiently and, thus, extend a limited budget). The system is designed to align (what is believed to be) the innate self-interest of regentes with the objective of maximizing ecosystem service provision. By encouraging the regente to seek profit within a system that requires competition, the cost of contract preparation may, as explained above, decline for some landowners wishing to participate. Doing so, however, actually fosters the very behavior presumed to be inherent.

Regentes are, actually, concerned with the social implications of their work, and they are motivated by altruistic factors. Nearly every regente with whom I spoke independently identified the social development benefits of the PSA, particularly with regard to small landowners (e.g. Interview \#9, 23 Jan 2012; Interview \#10, 23 Jan 2012; Interview \#11, 16 Jan 2012; Interview \#2, 30 Jan 2012). One, for example, referred to material improvements in participants' lives; "they are able to buy a motorcycle or car, or improve the path to their house. ...or [they] can at least pay for colectivos [rural shared taxis] and get the [school] uniform for their family" (Interview \#10, 23 Jan 2012). Another explained that many of these families "don't have very much money or not very much education ... it's good to help them" through enrollment in the PSA (Interview \#9, 23 Jan 2012). Even a private regente, within a profit-driven firm, stressed the importance of working with small owners and expressed desire to provide economic assistance in the form of ecosystem service payments. However, he also explained that he would not be able to generate a living wage if he did so (Interview \#2, 30 Jan 2012). Rather than pursue social objectives, the regente must pursue economic efficiency in order to survive in the competitive system. They are not driven by an inherent self-interest to maximize personal gain; they are placed within a system that encourages, in fact demands, such behavior.

The private regente with whom I spoke cannot be blamed for seeking profit and neglecting the smallest landowners. As he explained, he must operate within the parameters of the program or place his livelihood at risk (Interview \#2, 30 Jan 2012); just like Engels, he must submit to the coercive laws of competition. Self-interest is not inherent to his character, but rather encouraged by the system in which he operates. Behavior that is ordinarily admonished under prevailing social norms is promoted by these

7 'ATAL' is a pseudonym to protect the identity and reputation of the organization. Specific names and descriptive characteristics have been fictionalized to ensure anonymity. 
conditions. The competitive system, which requires profit maximization, is normalizing self-interest. Once it is socially acceptable (indeed economically preferable) to be self-interested, it becomes far easier to take a decision that is as seemingly asocial as swiping ATAL's contracts. Why wouldn't ATAL's regente keep hold of the contracts if they were in his name, he had labored to produce them, and they provided him with stability within a highly competitive system? Essentially, the competitive system is making such behavior permissible. It is in no way 'natural' for individuals to act in self-interested ways: self-interest is encouraged by the very systems designed to harness it.

\section{A viable alternative?}

In order to address the problem of unevenly distributed benefits from competitive contracting, and the more fundamental changes to environmental governance that come along with it, regente compensation would need to be a function of something other than contract size - that is, regentes would need to be paid in some way other than by a percentage of the contract value. Removal of the incentive to favor large properties would allow regentes to make contracting decisions for reasons other than their effect on the bottom line. The assumption of those who favor the independent contractors model, however, is that only a competitive system can be efficient and that contracting based on more equitable flat-rates (regardless of contract size or location) would result in wasteful administration expenses.

This position derives from an oversimplified conception of human behavior which presumes regentes will charge as much as possible unless checked by competitive market forces. As McAfee suggests, however, "economically "rational" behaviour aimed at individual gain is often less determinant than social obligations and communal norms" (2012: 118). This is certainly the case with with one regente who explained that he continues to offer his services through a community development organization in spite of the fact that he could earn more drafting PSA contracts independently (Interview \#9, 23 Jan 2012). Relying on this sort of social responsibility, it is possible to envision a model that spreads enrollment fees across the population without compromising regente performance or raising the overall cost of administration (lowered rates for small landowners could be offset by only marginal increases for large ones). In fact, such a model existed in Costa Rica until it was undermined by further neoliberalization that took the form of individualizing landowner participation. A form of collective participation, aimed at distributing costs, previously allowed small landowners to pool their resources and enter the program for a much lower fee.

\section{Competition vs. Cooperation}

\section{Group contracting through 'contratos globales'}

The contratos globales, or 'global contracts', were developed early in the program's evolution as a form of group contracting intended to level transaction costs and make it no more expensive for small landowners to participate than it is for large ones. ${ }^{8}$ They were developed in direct recognition of the high fixed costs of contract preparation and comparative disadvantage for small landowners (Pagiola et al. 2005; Porras et al. 2013). The idea was that landowners could pool their resources under a single contract, distribute regente fees across the group and, thus, reduce the per-hectare rate for all involved. This provided an entry point for disadvantaged individuals that would otherwise have found accessing the program (and its benefits) prohibitively expensive. In addition, grouping supported small owner participation by helping lesseducated and poorer farmers to navigate complex application and management procedures (Zbinden and Lee 2005).

These contracts were typically coordinated by non-governmental organizations and farmers' cooperatives, which grouped the landowners of local communities and assisted their PSA contract preparation. Many small landowners could band together in these groups to form larger contracts that would

\footnotetext{
${ }^{8}$ Note that these are not global in the sense that they are international or worldwide; they are simply 'global' to the
} members of the group. 
be more appealing to regentes. Benefiting from greater 'economies of scale', regentes could then offer lower rates than they otherwise could to any single member of the group; it was an efficiency gain that did not require a competitive framework. A single contract was issued at the end of the process, with all members of the group agreeing to the terms of the inscribed management plan. Payments from the group's enrollment were then distributed proportionally to members according to the amount of land each held.

Initial uptake was high. The group contracting mechanism was instrumental in building a base of participating landowners. In the first year of the program, nearly $60 \%$ of program funds were disbursed to participants in these groups (Porras 2010), with some cantons reaching upwards of 90\% (Bosselmann and Lund 2013). FONAFIFO relied on established conservation groups, agricultural associations, and community organizations to promote the PSA and recruit participants through these means. NGOs such as ASANA were engaged for exactly this purpose. The use of the grouping mechanism was not only extensive in the beginning, it was also touted by a broad range of actors as an important tool for integrating the poor. Bennett and Henninger (2008), for example, highlight the mechanism in their report to an international forum of legislators as a key strategy for distributing transaction costs so that the poor are not excluded. Even the World Bank supported group contracting (initially) by providing "training and technical support" to NGOs through the Ecomarkets project (World Bank 2007: 45-6). The mechanism, however, was met with several challenges, including how to handle instances of individual non-compliance and ownership change within the groups.

As designed, problems with single members could cause payment delays or even contract invalidation for the entire group (Porras 2010). Most often this occurred when group members wanted to sell their land or make changes to its status; outright breach of contract by members was unusual (Interview \#11, 16 Jan 2012). When these problems occurred, however, the contract had to be re-written, suspending payments and incurring new expenses. On occasion, such incidents escalated to crisis point. ASANA, for example, was once accused of stealing payments from its group members on a contract that was undergoing one of these adjustments (Interview \#6, 13 Jan 2012). The dispute was eventually resolved when the contract was restored (Interview \#6, 13 Jan 2012), but issues such as this sealed the fate of the contratos globales.

\section{Individualization}

A consensus emerged that the grouping mechanism was flawed, mainly in that it lacked dispute resolution procedures and the ability to handle individual ownership change (Interview \#12, 12 Dec 2011). In response to these problems, FONAFIFO revised the mechanism to culminate in individual contracts (Pagiola 2008; Porras et al. 2013) - the scale at which participating landowners cooperate was shifted downwards. As one official explained, group contracts are no longer signed or managed by the coordinating NGO. NGOs "do the work with small landowners ..., but at the moment of signing ..., each individual landowner signs a contract" (Interview \#12, 12 Dec 2011). This, of course, provides a solution to the ownership change and partial compliance problems, but it also undermines the coherence of collective participation.

In effect, the 'group' only exists during the recruitment stage. Once the NGO has found willing participants, individual management plans are drawn, and individual contracts are issued. These changes diminish the role of NGOs from coordinators of collective participation to the equivalent of an independent private regente - that is, NGOs no longer orchestrate communal action, they simply provide contracting services to disparate actors. Furthermore, the individual contracts mean that many of the fixed-costs of participation are replicated across the former group and transferred to each of its members; the regente must manage multiple sets of paperwork, have multiple billing and accounting ledgers, and arrange multiple individual inspections each year. This negates the efficiency gains from the greater economies of scale and results in "much smaller savings" (Pagiola 2008: 722) for the landowners who participate, further compounding the problem of large landowner advantage. In the competitive system, large landowners enjoy lower regente fees, so they can do quite well outside of these groups - indeed, they may even do better (Interview \#6, 13 Jan 2012). The small owners, on the other hand, are confronted with higher rates outside of these groups and, thus, lose out in the shift from collective to individual participation. 
Obviously, these changes to group contracting are far more significant than simple procedural modifications (i.e. they are more than a simple change to how contracts are issued). They effectively constitute the wholesale individualization of participation. In fact, the practice of grouping has changed so fundamentally that an official at FONAFIFO characterizes the contratos globales as having ended completely (Interview \#13, 15 Feb 2012). Indeed, the program's operations manual, the annual document issued by FONAFIFO and MINAE that sets guidelines for the program, contains no reference to grouping after 2003 (MINAE 2003). It is clear that the changes to group contracting were not as much a fix to the administrative challenges of collective participation as they were an altogether abandonment of the mechanism.

With the elimination of grouping, small landowners have lost not only their ability to defray and distribute administrative costs of participating in the PSA, they have lost the support of the institutions that assisted their participation as those institutions are drawn into the competitive system. While Porras et al. (2013) have suggested that this issue has been mitigated by establishment of regional FONAFIFO offices, the move represents an important shift in the program towards neoliberal individualism. The administrators of forest policy have made "a clear choice in favor of market-oriented conservation and reforestation instead of support for community development or cooperative behavior" (Silva 2003: 113).

The particular scale at which the tensions between competition and cooperation are mediated is by no means arbitrary. It is deliberately produced to achieve a particular economic vision and to maintain a particular balance of power. As Smith points out, "the demarcation of scale [is] absolutely central to the processes and politics of uneven geographical development" (2003: 229). The decision to individualize both participation and contracting is a highly political one that favors the largest and wealthiest landowners. During the recent transformation of Costa Rican forestry, the scale at which competition and cooperation operate was shifted to achieve specific political and economic ends. In this case, it has been the reorganization of the program according to neoliberal ideals that elevate economic efficiency over social or environmental responsibility.

\section{Conclusion: the coercive laws of competition in a neoliberal era}

The task of this article has been to illuminate the social and ecological implications of two scalar shifts in mediating between competition and cooperation in PSA contracting - one concerning the individualization of forestry work through the creation of the competitive regencia system, and one concerning the individualization of landowner participation through the removal of cooperative group contracting. Beyond the immediate implications for Costa Rica, however, the purpose of this article has been to provide a context in which to explore (and re-conceptualize) the coercive laws of competition within a neoliberalized economy.

The context in which Marx formulated his ideas on the coercive laws of competition is starkly different to that which is found in Costa Rican forestry. Classical industrial capitalism entails a mode of production that is bound in a clear distinction between those who own the means of production and those who labor to add value. In this context, economic competition occurs between individual capitalists vying to capture greater market share, and the workers are merely the social machinery to this end. Marx's conceptualization of the coercive laws, however, drew the link from this competition back to class struggle. In other words, he argued that competition between individual capitalists was ultimately still rooted in the struggle between classes.

Marx made this connection in the way that competition drives productivity-raising innovation. In a classical industrial economy, increasing productivity produces an increase in the 'rate of exploitation.' As Harvey explains, this is because increased productivity means a decrease in the value of the bundle of commodities that a laborer needs to survive or, in other words, a decrease in the value of labor-power (2010b: 163). Devalued labor-power means a decrease in the capital that must be given over to wages; that is, a decrease in the variable capital required for production. And since the rate of exploitation is determined by the ratio of surplus-value to variable capital, exploitation goes up as productivity increases (Harvey 2010b: 164). 
If we think about industrial capitalism today - for example, in Chinese manufacturing or the Bangladeshi garment industry - the relation between capital and labor is very similar and this explanation is still very relevant. But if we think about a fractured service economy - for example, the one that has emerged around PSA contracting in Costa Rica or, perhaps, the new individualized worker-owner economies of Uber,

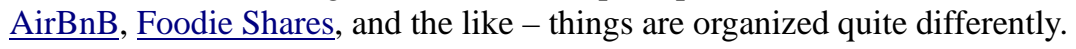

Deregulation and decentralization of forestry in Costa Rica has resulted in the individualization of labor, so that foresters have become independent, private contractors that must compete in every way. They operate independently in an open labor market, and they are ultimately self-employed. In this case, it becomes unclear who exactly are the capitalists and who are the laborers. Regentes act simultaneously as capitalist and laborer, complicating the explanation Marx has provided for understanding class struggle in a competitive economy. The question is: what are the conceptual implications for the coercive laws when the economy is organized in such a way? How can we understand the relation between capital and labor when they are embodied within a single individual? Essentially, what effect has neoliberalization had on the way the coercive laws of competition operate? The outlines of an answer to these questions can be found in the Costa Rican case presented above.

In an individualized economy, composed of independent capitalist-workers, it is necessary to look beyond the 'rate of exploitation' to understand the coercive laws of competition because it makes no sense to talk about capturing a greater portion of a person's own surplus-value. If the relationship between capital and labor is embodied within a single individual, it is not possible to explain increased exploitation as the dispossession of surplus-value. Instead, it is necessary to re-think how an individual might begin to engage in a form of self-exploitation and about how competition encourages ethically questionable behavior. The former relates to the way that an individual may force him- or herself to achieve levels of productivity that go beyond what is required for the provision of basic life-needs, simply to be competitive with other individuals in the economy (a condition perhaps familiar to many academics). Playing multiple roles simultaneously, an individual may act at certain times as a capitalist that exploits his or her own role as a worker. The rise in productivity that this produces then leads to a decline in the value of his or her own labor-power and, indeed, a decline in the value of labor-power of other capitalist-workers performing the same task. As I showed in the Costa Rican case, competition forced regentes to lower rates, effectively increasing productivity and, since they needed to maintain a standard of living, also their labor loads. Due to diminishing economies of scale, the benefits of this increasing productivity were also delivered unevenly. The most harmful consequence, however, is rooted in the way that competition coerced regentes into adopting ethically questionable practices, the way it edged out alternative motivations for conservation, and the way it undermined resistance to profit-oriented decision-making.

It is necessary to think differently about the coercive laws of competition, absent the relationship between capital and labor in Marx's classical example. When neoliberal ideals produce an economy of individualized private worker-capitalists, there may be no direct appropriation of surplus-value, but the coercive laws do still work to pull ever-greater dimensions of our life-world under capital's moral economy. This can be understood, as before, with regard to the necessity that actors within a capitalist system must protect and expand their market share in order to remain viable; if regentes do not adopt the (sometimes questionable) practices of their rivals, they will be rendered uncompetitive and ensured of failure. Regardless of conscience, or whatever other motivations they might have, actors are constrained by the competitive system in which they operate; if they are not willing to submit to the coercive laws, there will always be a competitor that is prepared to do so. The coercive laws of competition must be handled differently in the context of an individualized neoliberal economy, but they are still very much at work in the way the capitalist system drives actors towards the lowest common denominator of ethical behavior.

\section{References}

Arsel, M. and B. Büscher. 2012. Nature ${ }^{\mathrm{TM}}$ Inc.: changes and continuities in neoliberal conservation and market-based environmental policy. Development and Change 43: 53-78. 
Bennett, K. and N. Henninger. 2008. Payments for Ecosystem Services in Costa Rica and Forest Law No. 7575. Washington: World Resources Institute.

Bosselmann, A.S. and J.F. Lund. 2013. Do intermediary institutions promote inclusiveness in PES programs? The case of Costa Rica. Geoforum 49: 50-60.

Brockington, D. and R. Duffy. 2010. Capitalism and conservation: the production and reproduction of biodiversity conservation. Antipode 42(3): 469-484.

Castree, N. 2008a. Neoliberalising nature: processes, effects, and evaluations. Environment and Planning A 40: $153-173$.

Castree, N. 2008b. Neoliberalising nature: the logics of deregulation and reregulation. Environment and Planning A 40: 131-152.

Chomitz, K.M., E. Brenes and L. Constantino. 1999. Financing environmental services. The Science of The Total Environment 240: 157-169.

Colegio. 2011. Valor de Visita Regencial (Value of Regency Visit). San Jose: Colegio de Ingenieros Agronomos, Costa Rica.

Decreto Ejecutivo. 2013. 37660-MINAET, 2013. <http://www.fonafifo.go.cr/text_files/servicios_ambientales/Decretos/ALCA74_23_04_2013.pdf> [accessed 29 April 2013].

Decreto Ejecutivo. 2013. 37784-MTSS, 2013. Fijacion de Salarios Minimos Para el Sector Privado (Fixing of Minimum Salaries for the Private Sector). San Jose: Government of Costa Rica. <http://www.gaceta.go.cr/pub/2013/07/10/COMP_10_07_2013.html\#_Toc361153395> [accessed 9 January 2015].

Engels, F. 1993 (1845). The condition of the working class in England. Oxford: Oxford University Press.

Evans, S. 1999. The green republic: a conservation history of Costa Rica. Austin: University of Texas Press.

Fletcher, R. 2010. Neoliberal environmentality: towards a poststructuralist political ecology of the conservation debate. Conservation and Society 8: 171-181.

Fletcher, R. and J. Breitling. 2012. Market mechanism or subsidy in disguise? Governing payment for environmental services in Costa Rica. Geoforum 43(3): 402-411.

FONAFIFO. 2005. Over a decade of action. San Jose: Ministry of Environment and Energy, Costa Rica.

Harvey, D. 2010a. A companion to Marx’s Capital. New York: Verso.

Harvey, D. 2010b. The enigma of capital: and the crises of capitalism. New York: Oxford University Press.

Heynen, N. and P. Robbins. 2005. The neoliberalization of nature: governance, privatization, enclosure and valuation. Capitalism Nature Socialism 16: 5-8.

Hunt, T. 2010. Marx's general: the revolutionary life of Friedrich Engels. New York: Holt.

Igoe, J. and D. Brockington. 2007. Neoliberal conservation: a brief introduction. Conservation and Society 5: 432-449.

Lansing, D. 2013. Understanding linkages between ecosystem service payments, forest plantations, and export agriculture. Geoforum 47: 103-112.

Lansing, D. 2014. Unequal access to payments for ecosystem services: the case of Costa Rica. Development and Change 45(6): 1310-1331.

Le Coq, J.F., Froger, G., Pesche, D., Legrand, T., and F. Saenz. 2015. Understanding the governance of the Payment for Environmental Services Programme in Costa Rica: a policy process perspective. Ecosystem Services 16: 253-265.

Marx, K. 1976 (1867). Capital, Volume I. New York: Penguin Books.

Matulis, B.S. 2013. The narrowing gap between vision and execution: neoliberalization of PES in Costa Rica. Geoforum 44(1): 253-260. 
Matulis, B.S. 2015. PES and property: the expansion of exclusionary land management practices in Costa Rica. Human Geography 8(2): 39-54.

Matulis, B.S. In Press. Persistent neoliberalization in PES: taxes, tariffs, and the World Bank in Costa Rica. Conservation and Society.

McAfee, K. 2012. The contradictory logic of global Ecosystem Services Markets. Development and Change 43: 105-131.

McCarthy, J. and S. Prudham. 2004. Neoliberal nature and the nature of neoliberalism. Geoforum 35: 275283.

MINAE. 2003. Manual de Procedimientos Para el Pago de Servicios Ambientales (Procedures Manual for the Payments for Environmental Services)

< http://www.fonafifo.go.cr/text_files/servicios_ambientales/Manuales/Manual2003.pdf> [accessed 27 February 2014].

Miranda, M., I. Porras and M. Moreno. 2003. Social impacts of the Payments for Environmental Services (PES) Scheme in Costa Rica. London: International Institute for Environment and Development.

Navarro, G. and H. Thiel. 2007. On the evolution of the Costa Rican forestry control system. Verifor.

Pagiola, S. 2008. Payments for environmental services in Costa Rica. Ecological Economics 65: 712-724.

Pagiola, S., A. Arcenas and G. Platais. 2005. Can Payments for Environmental Services help reduce poverty? World Development 33: 237-253.

Porras, I. 2010. Fair and Green? Social impacts of payments for environmental services in Costa Rica. London: International Institute for Environment and Development.

Porras, I., Barton, D.N., Miranda, M., and A. Chacón-Cascante. 2013. Learning from 20 year of Payments for Ecosystem Services in Costa Rica. London: International Institute for Environment and Development.

Robertson, M. 2004. The neoliberalization of ecosystem services: wetland mitigation banking and problems in environmental governance. Geoforum 35: 361-373.

Sage, L. and O. Sánchez. 2002. Evolucion esperada para el mercado de pago de servicios ambientals en Costa Rica. Revista Forestal Centroamericana 37: 72-73.

Silva, E. 2003. Selling sustainable development and shortchanging social ecology in Costa Rican forest policy. Latin American Politics and Society 45: 93-127.

Smith, N. 2003 (1995). Remaking scale: competition and cooperation in pre-national and post-national Europe. In Brenner, N., Jessop, B., Jones, M. and G. Macleod (eds.). State/Space: a reader. Malden, MA: Blackwell. Pp. 227-238.

Sullivan, S. 2013. Banking nature? The spectacular financialisation of environmental conservation. Antipode 45(1): 198-217.

Swyngedouw, E. 2005. Dispossessing $\mathrm{H}_{2} \mathrm{O}$ : the contested terrain of water privatization. Capitalism, Nature Socialism 16: 81-98.

World Bank. 2007. Ecomarkets ICR. Washington: The World Bank Group.

Zbinden, S. and D.R. Lee. 2005. Paying for environmental services: an analysis of participation in Costa Rica's PSA Program. World Development 33: 255-272. 